\section{(C) OPEN ACCESS}

\title{
Tobacco industry's elaborate attempts to control a global track and trace system and fundamentally undermine the Illicit Trade Protocol
}

\author{
Anna B Gilmore, ${ }^{1,2}$ Allen W A Gallagher, ${ }^{1,2}$ Andy Rowell ${ }^{1,2}$
}

\begin{abstract}
- Additional material is published online only. To view please visit the journal online (http://dx.doi.org/10.1136/ tobaccocontrol-2017-054191).

${ }^{1}$ Tobacco Control Research Group, University of Bath, Bath, UK

${ }^{2}$ UK Centre of Tobacco and Alcohol Studies, University of Bath, Bath, UK
\end{abstract}

\section{Correspondence to}

Professor Anna B Gilmore, Department for Health, University of Bath, Bath BA2 7AY, UK; a.gilmore@bath.ac.uk

Received 7 December 2017 Revised 12 April 2018 Accepted 16 April 2018 Published Online First 13 June 2018

\section{SLinked}

- http://dx.doi.org/10.1136/ tobaccocontrol-2018-054352

Check for updates

To cite: Gilmore $A B$, Gallagher AWA, Rowell A. Tob Control

2019:28:127-140.

\section{ABSTRACT}

Background The Illicit Trade Protocol (ITP) requires a global track and trace (T\&T) system to reduce tobacco smuggling. Given the tobacco industry's (TI) historical involvement in tobacco smuggling, it stipulates that T\&T 'shall not be performed by or delegated to the tobacco industry'. This paper explores the rationale for \& nature of the TI's effors to influence the ITP \& its T\&T system.

Methods Analysis of leaked TI documents and publicly available data; , investigation of front groups, trademark and patent ownership.

Findings Growing \& diverse sources of evidence indicate that the TI remains involved in tobacco smuggling and that TI cigarettes account for around two-thirds of the illicit cigarette market. The TI therefore has a vested interest in controlling the global T\&T system aimed to curtail this behaviour. To this end, Philip Morris International (PMI) adapted its pack marker system, Codentify, to meet T\&T requirements, licensed it for free to its three major competitors who then collectively promoted it to governments using front groups and third parties including companies claiming to be independent despite clear TI links. PMI also sought to suggest Codentify was independent by selling some parts of its intellectual property on Codentify while retaining others, leaving a complex web of shared interests. In Africa, British American Tobacco used payments to obtain data suggesting its smaller competitor companies were evading taxes and secure influence with tax authorities. Regulatory capture has been enhanced by a public relations effort involving TI funding for conferences, training, research, and international police and anti-corruption organisations. Collectively this has created public messaging and a powerful network of organisations supportive of the TI's misleading postion on illicit.

Conclusions Governments should assume the TI seeks to control T\&T systems in order to avoid scrutiny and minimise excise tax payments and that any T\&T system based on Codentify, on intellectual property currently or previously owned by the TI, or being promoted or implemented by companies with TI links, is incompatible with the ITP and would not serve to reduce illicit trade.

\section{INTRODUCTION}

The Framework Convention on Tobacco Control's (FCTC) Illicit Trade Protocol (ITP), adopted in November 2012 following 4 years of negotiation ${ }^{1}$ (see Timeline in table 1), aims to eliminate all forms of illicit tobacco, but focuses particularly on securing the supply chain of legally manufactured tobacco products. A global track and trace (T\&T) system which can track a tobacco product through its distribution chain and, should it enter the illicit market, 'trace' it back to determine at what point it entered the illicit channel is therefore central. ${ }^{1}$ This will be achieved by each party to the protocol requiring that every pack manufactured in or imported to their territory has a unique, secure marking providing information on manufacture, shipping and distribution. This focus and the stipulation that obligations for T\&T systems 'shall not be performed by or delegated to the tobacco industry' were driven by overwhelming evidence of the transnational tobacco companies' (TTCs) historical involvement in cigarette smuggling. ${ }^{1-10}$

This paper aims to examine the nature and purpose of TTC efforts to undermine the ITP and the implications for global tobacco control. Through analysing data on the structure of the illicit tobacco market, leaked industry documents, patent and trademark filings and investigating front groups, it shows that TTCs are engaged in an elaborate campaign to control the global T\&T system the ITP envisages by promoting its own pack marker system, Codentify (box 1), as the T\&T system of choice.

\section{EVIDENCE OF HISTORICAL AND ONGOING TOBACCO INDUSTRY INVOLVEMENT IN TOBACCO SMUGGLING \\ Pre-1990}

TTCs have a long history of complicity in tobacco smuggling. ${ }^{24-10}$ They profit when they sell to the distributor regardless of whether their product then enters the illegal market. ${ }^{4}$ Tobacco smuggling can benefit them in numerous ways (box 2).

Through the 1990s, overwhelming evidence from TTC documents detailed their involvement in global cigarette smuggling. ${ }^{2-10}$ The scale was unprecedented-a third of global cigarette exports were estimated to end up on the illicit market ${ }^{4}$ with TTCs supplying some markets almost entirely via illicit channels. ${ }^{9}{ }^{10} \mathrm{By}$ the late 1990 s, investigations and lawsuits (table 1$)^{11-14}$ had led to guilty verdicts $^{1415}$ and legal agreements including between the European Union (EU) and all four TTCsPhilip Morris International (PMI), British American Tobacco (BAT), Japan Tobacco International (JTI) and Imperial Tobacco. ${ }^{16}$

Post-1990: a change in the competitive landscape for illicit tobacco products

With their activities exposed, TTCs changed their export practices. ${ }^{17}$ Total illicit cigarette volumes declined, ${ }^{17}$ but new types of illicit products began 
Table 1 Timeline of events, 1998 to 2017

\begin{tabular}{ll}
\hline Timeline & $\begin{array}{l}\text { Framework Convention on Tobacco } \\
\text { Control (FCTC) and Illicit Trade } \\
\text { Protocol (ITP) }\end{array}$ \\
\hline Date & \\
\hline December 1998 & \\
June 1999 & \\
\hline December 1999 & \\
\hline June 2000 & \\
\hline November 2000 & \\
\hline August 2001 & \\
\hline January 2002 & \\
\hline October 2002 & \\
\hline February 2003 & \\
\hline May 2003 & \\
\hline July 2004 & \\
\hline
\end{tabular}

European Union (EU)

Tobacco industry (TI)

EU investigation of transnational tobacco company

(TTC) cigarette smuggling starts ${ }^{16}$

An affiliate of RJ Reynolds pleads guilty in US tobacco smuggling lawsuit and is fined $\$ 15$ million $^{170}$

RJR MacDonald's parent company under investigation by the Royal Canadian Mounted Police (RCMP) for complicity in tobacco smuggling between 1989 and $1994^{171}$

Through US Courts, the Canadian government sues RJ Reynolds and affiliates in alleging they were part of a conspiracy to smuggle cigarettes into Canada ${ }^{12}$

Canada's lawsuit rejected on the grounds that US courts cannot be used to collect the taxes of another country $^{172}$

EU files Racketeer Infuenced \& Corrupt Organizations Act (RICO) case in New York Court against

TTCs accusing the companies of 'an ongoing global scheme to smuggle cigarettes'16 173174

10 EU member states join the lawsuit ${ }^{174}$

Additional charges filed against Japan Tobacco International (JTI) and its affiliates ${ }^{175}$

Additional allegations filed against RJR MacDonald ${ }^{16}$

The RCMP file criminal charges against RJ Reynolds and affiliates over cigarette smuggling in the $1990 \mathrm{~s}^{14}$

July 2004

EU and member states drop case against

Phillip Morris International (PMI) in return for enforceable and legally binding agreement. PMI pays the EC $\$ 1250$ million over 12 years. ${ }^{16}$ Through this and subsequent agreements with the other TTCs, they collectively had to make payments of US\$1.9 billion to the EU and its member states, additional payments if their tobacco products were, through seizures, found on the illicit market (although only in large numbers) ${ }^{16}$ and to mark their products with trackable codes ${ }^{177-180}$

October 2004

PMI files priority international patent for 'methods and systems for marking, tracking and authentication of products' (Codentify) ${ }^{77}$

February 2005

The FCTC enters into force ${ }^{181}$

September 2005

International Codentify patent filed ${ }^{77}$

February 2006

Conference of the Parties (COP) 1-

officers elected and main committees established $^{182}$

Codentify patent enters the European regional phase $\mathrm{e}^{183}$

September 2006

June 2007

COP 2-decision to establish an intergovernmental negotiating body (INB) on the ITP ${ }^{182}$

December 2007

EU reaches agreement on illicit trade with

JTI. JTI agrees to pay the EC $\$ 400$ million over 15 years ${ }^{179}$

February $2008 \quad$ INB — first meeting (negotiations for ITP begin) ${ }^{182}$

During 2008-September 2010, the four major tobacco companies in Canada plead guilty to tobacco smuggling and were collectively fined \$C1.7 billion ${ }^{14}$

October $2008 \quad$ INB, second meeting ${ }^{182}$

November $2008 \quad$ COP $3^{182}$

February 2009

April 2009

June 2009

March 2010

INB, third meeting ${ }^{182}$

July 2010

INB, fourth meeting ${ }^{182}$

$\begin{array}{ll}\text { September } 2010 & \text { EU reaches } \\ & 20 \text { years }{ }^{178}\end{array}$

EU reaches agreement on illicit trade with British American Tobacco (BAT). BAT agrees to pay the EC \$200million over 20 years ${ }^{177}$

EU reaches agreement on illicit trade with Imperial Tobacco Limited. Imperial agrees to pay the EC $\$ 300$ over

$\begin{array}{ll}\text { September } 2010 & \text { years }^{178}\end{array}$

Codentify patent is granted by Eurasian Patent Organization $^{184}$

Codentify patent is granted in Europe ${ }^{185}$ 


\begin{tabular}{|c|c|c|c|}
\hline \multicolumn{4}{|l|}{ Timeline } \\
\hline Date & $\begin{array}{l}\text { Framework Convention on Tobacco } \\
\text { Control (FCTC) and Illicit Trade } \\
\text { Protocol (ITP) }\end{array}$ & European Union (EU) & Tobacco industry (TI) \\
\hline November 2010 & $\begin{array}{l}\text { COP } 4 \text { - decision to establish informal } \\
\text { working group on the ITP }\end{array}$ & & $\begin{array}{l}\text { PMI licences Codentify for free to its main } \\
\text { competitors. }^{65} \text { Tobacco Industry Working Group on } \\
\text { Digital Tax Verification formed }{ }^{67}\end{array}$ \\
\hline May 2011 & & & $\begin{array}{l}\text { The first Project Star report published on illicit tobacco } \\
\text { in the EU, commissioned by PMI from } \mathrm{KPMG}^{25}\end{array}$ \\
\hline July 2011 & $\begin{array}{l}\text { ITP working group holds its first } \\
\text { meeting }\end{array}$ & & \\
\hline October 2011 & & & $\begin{array}{l}\text { Digital Coding and Tracking Association (DCTA) } \\
\text { registered in Zurich }{ }^{187}\end{array}$ \\
\hline March 2012 & INB, fifth meeting $^{182}$ & & \\
\hline June 2012 & & & $\begin{array}{l}\text { PMI makes } € 15 \text { million donation to Interpol to work } \\
\text { with DCTA }\end{array}$ \\
\hline November 2012 & $\begin{array}{l}\text { COP 5-ITP adopted and Interpol (in } \\
\text { receipt of pounds from PMI) applies for } \\
\text { observer status }\end{array}$ & & \\
\hline December 2012 & & & $\begin{array}{l}\text { SICPA awarded Kenyan Revenue Authority tender, } \\
\text { despite lobbying efforts for Codentify by BAT and } \\
\text { FractureCode }\end{array}$ \\
\hline January 2013 & ITP opened for signature $\mathrm{e}^{190}$ & & \\
\hline April 2013 & & & $\begin{array}{l}\text { European Codentify patent is updated to change the } \\
\text { applicant from PMI to the DCTA }\end{array}$ \\
\hline September 2013 & & & $\begin{array}{l}\text { PMI donates } € 55000 \text { to International Anti-Corruption } \\
\text { Academy (initiated by European Antifraud Office and } \\
\text { UN Office on Drugs and Crime) }\end{array}$ \\
\hline December 2013 & EU signs ITP 192 & & US Codentify patent is filed ${ }^{193}$ \\
\hline April 2014 & & $\begin{array}{l}\text { The Revised Tobacco Products Directive (TPD) agreed. } \\
\text { Articles } 15 \text { and16 relate to T\&T and operationalise the } \\
\text { ITP in the EU } U^{194}\end{array}$ & $\begin{array}{l}\text { DCTA is the major sponsor of World Customs } \\
\text { Organization conference on illicit tobacco }\end{array}$ \\
\hline May 2014 & & & $\begin{array}{l}\text { KPMG \& GS1 UK release a DCTA-funded report } \\
\text { promoting Codentify }\end{array}$ \\
\hline June 2014 & & & $\begin{array}{l}\text { First Project SUN report is published-a continuation } \\
\text { of Project Star but now commissioned by all TTCs } s^{195}\end{array}$ \\
\hline October 2014 & $\begin{array}{l}\text { COP } 6 \text { - Report on the status of the ITP. } \\
\text { Request for establishment of ITP expert } \\
\text { panel }^{182}\end{array}$ & & \\
\hline November 2014 & & & $\begin{array}{l}\text { BAT is fined } f 650000 \text { (later reduced to } f 10000)^{35} \text { for } \\
\text { oversupplying products to Belgium }\end{array}$ \\
\hline March 2015 & & Feasibility assessment on EU T\&T system published ${ }^{117}$ & \\
\hline June 2015 & & & Coalition Against Illicit Trade is formed ${ }^{118}$ \\
\hline April 2016 & & & Inexto established ${ }^{101}$ \\
\hline May 2016 & $\begin{array}{l}\text { Coordinating meeting of the ITP expert } \\
\text { panel }\end{array}$ & & PMI launches PMI IMPACT ${ }^{197}$ \\
\hline June 2016 & EU ratifies ITP198 & $\begin{array}{l}\text { Inception impact assessment for delegated acts under } \\
\text { Articles } 15 \text { and } 16 \text { of TPD published }{ }^{200}\end{array}$ & $\begin{array}{l}\text { DCTA announces that it has sold Codentify to Inexto, } \\
\text { and PMI claims it now complies with the TPD } \\
\text { PMI IMPACT announces first call for proposals to } \\
\text { fund }^{160}\end{array}$ \\
\hline July 2016 & & $\begin{array}{l}\text { EU agreement on illicit trade with PMI expires } \\
\text { EU public consultation on EU system of T\&T in line } \\
\text { with Articles } 15 \text { and } 16 \text { of the TPD (ends in November } \\
2016)^{202}\end{array}$ & \\
\hline September 2016 & & & $\begin{array}{l}\text { DCTA transfers ownership of Codentify's European } \\
\text { patent to Inexto }{ }^{203}\end{array}$ \\
\hline November 2016 & $\begin{array}{l}\text { COP 7-Parties urged not to consider } \\
\text { tobacco industry proposals or assistance } \\
\text { on T\&T. Requests ITP expert panel to } \\
\text { report at next COP }\end{array}$ & & $\begin{array}{l}\text { Two trademarks for Codentify, covering Switzerland } \\
\text { and the EU member states, are transferred to } \\
\text { Inexto }{ }^{112-114}\end{array}$ \\
\hline June 2017 & First meeting of ITP expert panel ${ }^{196}$ & & \\
\hline September 2017 & & $\begin{array}{l}\text { Consultation on draft implementing regulation on } \\
\text { technical standards for T\&T system }\end{array}$ & $\begin{array}{l}\text { PMI IMPACT funds } 32 \text { projects and many led by } \\
\text { organisations with previous TI links }{ }^{159}\end{array}$ \\
\hline
\end{tabular}




\section{Box 1 Codentify versus enhanced tax stamp systems}

Codentify: A code-generating system developed and promoted by the transnational tobacco companies (TTCS). Initially developed as a non-secure authentication system (to determine if a product is authentic or counterfeit), it was subsequently adapted for use as a digital tax verification system. ${ }^{65} 204$ Installed at the production line, the system prints two unique codes on each tobacco/cigarette packet-a production information code detailing, inter alia, line and time of production, and a 12-character alphanumeric code generated through an encrypted digital signature to the production information code. ${ }^{66} 193$ There is no linked security feature. Tobacco industry insiders, academics and the Framework Convention on Tobacco Control's Secretariat have criticised Codentify as an inefficient ${ }^{205}$ and ineffective track and trace (T\&T) mechanism. ${ }^{79206}$

Enhanced stamp systems: Developed initially to focus on individual packs (not cartons, master cases or pallets) intended for the domestic market and to enable volume reporting and revenue collection, tax stamps have now been advanced through the addition of enhanced security features and database linkage to allow T\&T and authentication of genuine versus counterfeit products. The key feature is the combination of digital (the unique identification code on a pack) and physical security elements (these may be overt, eg, holograms; covert, eg, fluorescent fibres; or forensic) which make new tax stamps difficult to counterfeit. ${ }^{167}$

Codentify-based system has close links to the tobacco industry, while tax stamp systems were developed independently. Tax stamp producers, also in the business of printing secure documents for government (passports, ID documents, currency), are subject to international standards that control their production and distribution processes.

to appear alongside tobacco industry illicit-counterfeits and cheap whites (box 3). ${ }^{17}{ }^{18}$ Simultaneously, TTCs sought to shift the issue from a public relations (PR) disaster where they were the pariah supplier of illicit product ${ }^{8}$ to a PR success story identifying them as both the victim of and solution to tobacco smuggling. ${ }^{6}$ They did so by using their resource advantage to purchase data, access and influence, ${ }^{6}$ exaggerate the threat of illicit tobacco (particularly counterfeit and cheap whites) and present them as a consequence of tobacco control policies. ${ }^{19-22}$

\section{Ongoing industry involvement: emerging evidence and data}

Recent data consistently show that at global, European and national level, the majority of the illicit cigarette market still comprises tobacco industry product (table 2). Latest estimates suggest that approximately $60 \%-70 \%$ of the illicit market is tobacco industry product with specific figures varying from $58 \%$ (2016, EU level, industry funded data) to 69\%-73\% (seizure data for 2011 and 2012 at global level and 2014 and 2016 at UK level). This has occurred despite the use of Codentify in, according to industry claims, over 100 countries worldwide (online supplementary appendix 1). ${ }^{23}$

By comparison, the problem of counterfeit, which the industry continuously emphasises, ${ }^{6} 19202425$ comprises only 5\%-8\% of the illicit market (other than in the 2016 Operation Henry data which are problematic-see footnote to Table 2). The contribution of cheap whites represents, in most of these data, around a fifth to a third of the illicit market. There has, however, been
Box 2 The ways in which tobacco smuggling can benefit transnational tobacco companies (TTCs)

- Smuggled tobacco has either no excise duties or duties from a lower tax jurisdiction applied. Consequently, it is sold for less than it should be. The cheaper a product, the more it sells, especially to the most price-sensitive smokers - the young and the least well off. ${ }^{6}$

- Smuggling undermines tobacco control measures making them less effective in reducing smoking. An obvious example is tobacco taxes, but because illicit product is not usually sold through standard outlets, it also undermines age of sale controls and licensing. ${ }^{617207}$

- Smuggling is a key market entry technique that the TTCs have used extensively ${ }^{208}$ to bypass tariff and non-tariff barriers to trade and move tobacco into closed or protected markets. Simultaneously, TTCs argue that the presence of illicit products signals a need for them to invest in that market (rather than resulting from their involvement in the illegal trade). ${ }^{9208}$

- TTCs use tobacco smuggling to oppose tobacco control policies, arguing that demand for the illicit product, rather than its supply, drives the problem and the tobacco control policy in question will only make this worse. Historically TTCs mainly applied this argument to tobacco taxes, ${ }^{24}$ often causing countries to reduce their tobacco excise rates. ${ }^{4207}$ The problem of tobacco smuggling is now used to oppose almost every tobacco control policy. ${ }^{1924209}$

Source: Adapted from Gilmore et al. ${ }^{6}$

some confusion in defining and measuring cheap whites. For example, industry-commissioned Project Star report, undertaken by KPMG, incorrectly classified the Imperial Tobacco brand, Classic, as a cheap white during a period (2006-2012) when it

Box 3 Types of illicit tobacco products now being seen

\section{Counterfeits}

- Products bearing a trademark of a cigarette manufacturer that are manufactured by a third party without consent from that cigarette manufacturer.

\section{Cheap whites (also known as illicit whites)}

- Non-transnational tobacco company (TTC)-branded cigarettes that are legally produced but have no legitimate market. This confusing term initially used by TTCs is defined by the European Commission as: 'brands manufactured legitimately in one market, either taxed for local consumption or untaxed for export, and sold knowingly to traders who transport them to another country where the products are sold illegally without domestic duty paid. ${ }^{210}$

\section{Tobacco industry illicit (tobacco industry product present in the illicit market)}

- Product of one of the cigarette manufacturers that was en route to, imported into, distributed in or sold in a jurisdiction in violation of that jurisdiction's fiscal laws. That this product was manufactured by a tobacco company does not imply the company is always responsible when that product ends up on the illicit market.

Source: Adapted from Gilmore et al. ${ }^{25}$ 
Table 2 The make-up of illicit cigarette market by type (tobacco industry illicit, cheap whites and counterfeit): recently available data at global, European and UK levels

\begin{tabular}{|c|c|c|c|c|c|c|c|c|c|c|}
\hline & 2007 & 2008 & 2009 & 2010 & 2011 & 2012 & 2013 & 2014 & 2015 & $2016 *$ \\
\hline \multicolumn{11}{|c|}{ Global (WCO data) } \\
\hline Illicit white & & & & & $20 \%$ & $25 \%$ & NA & NA & NA & \\
\hline Counterfeit & & & & & $7 \%$ & $7 \%$ & $4 \%$ & $2 \%$ & $2 \%$ & \\
\hline TI illicit & & & & & $73 \%$ & $69 \%$ & NA & NA & NA & \\
\hline \multicolumn{11}{|c|}{ EU (Project Star and Project Sun) } \\
\hline Illicit white & $4 \%$ & $8 \%$ & $13 \%$ & $15 \%$ & $23 \%$ & $26 \%$ & $33 \%$ & $37 \%$ & $35 \%$ & $34 \%$ \\
\hline Counterfeit† & $6 \%$ & $6 \%$ & $5 \%$ & $5 \%$ & $4 \%$ & $0 \%$ & $6 \%$ & $7 \%$ & $9 \%$ & $8 \%$ \\
\hline TI illicit & $89 \%$ & $86 \%$ & $82 \%$ & $80 \%$ & $74 \%$ & $74 \%$ & $61 \%$ & $56 \%$ & $56 \%$ & $58 \%$ \\
\hline \multicolumn{11}{|c|}{ UK (Operation Henry 1\&2) } \\
\hline Illicit whites & & & & & & & & $24 \%$ & & $14 \%$ \\
\hline Counterfeit & & & & & & & & $5 \%$ & & $18 \%$ \\
\hline TI illicitł & & & & & & & & $72 \%$ & & $69 \%$ \\
\hline
\end{tabular}

Blank cells are where no reports were published. NA indicates where a report was published but a specific data item was not available.

WCO data taken from the WCO Illicit Trade Reports: 2014 and 2015 data from 2015 report $^{211} ; 2013$ data from 2014 report ${ }^{212}$; 2012 and 2011 data from 2012 report (the first such report) ${ }^{213}$ (please note figures differ very slightly between reports) (based on seizure data).

EU data taken from the Project Sun and Project Star reports published by KPMG and funded by the tobacco industry and the Royal United Services Institute ${ }^{214-220}$ (based on industry data and modelling by KPMG).

UK data taken from the Operation Henry reports published by the Chartered Trading Standards Institute and commissioned by the Department of Health Tobacco Policy Team ${ }^{27} 221$ (based on systematically collected seizure data).

*2016 Operation Henry data were collected from December 2015 to April 2016 inclusive.

†The Counterfeit data in the Project Sun/Star reports comprise just counterfeit PMI brands from 2007 to 2011 and counterfeited brands for all four TTCs from 2013 onward. ¥The 2016 Operation Henry report listed the two most seized products, West and Winston which are tobacco industry brands (sold in the UK by Imperial Tobacco and Japan Tobacco International, respectively), as cheap white products. In our analysis, these have instead been included as TI illicits. This is more likely to give an accurate picture because, although it is unclear if a determination was made as to whether these products were genuine or counterfeit, as they are not widely sold in the UK it is thought unlikely that counterfeiters would target them at the UK market.

EU, European Union; PMI, Philip Morris International; TI, tobacco industry; TTCs, transnational tobacco companies; WCO, World Customs Organization.

was one of the most seized brands in Europe. ${ }^{26}$ Similarly, in the latest Operation Henry report, the two most seized brands, West and Winston, were coded as cheap whites yet are TTC brands. ${ }^{27}$ Consequently, data may underestimate tobacco industry illicit.

While the smuggling of some tobacco industry cigarettes may be outside their control, the sheer volume suggests some involvement. Whistleblowers, ${ }^{28}$ researchers, ${ }^{16}$ investigative journalists, ${ }^{29} 30$ alongside government reports, ${ }^{31}{ }^{32}$ investigations, ${ }^{33}$ accusations $^{33}$ and fines ${ }^{34}$ suggest that industry involvement has continued since the 1990s. At best, evidence indicates that tobacco companies are failing to control their supply chain, overproducing in some markets (eg, Ukraine ${ }^{29}$ ) and oversupplying to others (eg, Belgium) in the knowledge their products will end up on the illicit market. At worst, ex-employees insist JTI remained actively involved, describing 'rampant smuggling' throughout the Middle East, Russia, Moldova and the Balkans. ${ }^{28}$ Leaked documents suggest that BAT staff suspected JTI was facilitating smuggling into the Democratic Republic of Congo $(\mathrm{DRC})^{36}{ }^{37}$ but that BAT also clandestinely moved millions of dollars in cash from Uganda to the DRC to buy tobacco leaf which was presumably then illegally exported. ${ }^{38} 39$ In 20112012, BAT cigarettes being distributed by a company previously implicated in tobacco smuggling were ending up in the illicit market across Africa, the Middle East and Europe with BAT staff agreeing not to discuss the problem by email. ${ }^{40-42}$

Evidence suggests that smaller tobacco companies in Africa are also involved in smuggling and that, despite evidence of its own involvement, ${ }^{33}$ 39-42 BAT sought to prove these companies were evading tax payments, using this knowledge to undermine them and gain influence with tax authorities. ${ }^{3033} 43-57$ In South Africa, critics claim BAT engaged in money laundering to fund a large spy network and used its funding and the data obtained to secure a seat on the multiagency Illicit-Tobacco Task Team where it could then drive the law enforcement agenda. 3343444857 While such detailed evidence is limited to South Africa, BAT documents indicate the company was also paying informants to obtain competitor data elsewhere in Africa and using these data, alongside payments to staff, ${ }^{585}$ to ingratiate itself with tax authorities. ${ }^{60-64}$ Collectively this evidence suggests a very real danger of regulatory capture.

\section{Implications for T\&T}

It is unsurprising that tobacco industry illicit has not fallen further given that the incentives (box 2) have hardly changed and, where evaluated, fines are too small to offer sufficient deterrent to ongoing involvement. ${ }^{1625}$ At EU level, for example, seizure payments paid by the TTCs from 2006 to 2012 cover only $0.08 \%$ of estimated government excise losses despite TTC product representing at least $74 \%$ of illicit tobacco over that period (table 2). ${ }^{1625}$

Effective and well-implemented T\&T systems run independently of the tobacco industry would make ongoing TTC involvement in illicit almost impossible. And, as they can only be applied to legally manufactured product, would disadvantage TTCs compared with operators selling counterfeit and cheap whites, providing an incentive for TTCs to control them.

\section{TOBACCO INDUSTRY INTERESTS IN AND INFLUENCE ON T\&T SYSTEMS: EVIDENCE FROM LEAKED INDUSTRY DOCUMENTS AND LINKED INVESTIGATIONS Tobacco industry's fears and aims}

Leaked industry documents highlight TTCs' fears and aims around illicit, tax stamps, T\&T systems and the ITP. ${ }^{65-69}$ In 2003, BAT outlined how the industry was perceived as 'part of the problem' in illicit yet needed 'to be part of solution to 
combat threat to our business'. ${ }^{68}$ It was identified as 'VITAL for Big Tobacco to be involved in shaping final regulation' in this area. ${ }^{68}$ To this end 'cooperation with Governments and Customs authorities worldwide' was key. $^{68}$ A later BAT document outlining the 'building blocks' of an Anti-Illicit Trade Advocacy strategy stressed the need 'To reinforce British American Tobacco as being part of solution, not part of the problem. ${ }^{70}$

Documents suggest TTCs feared the implementation of enhanced tax stamp systems such as those of a leading company in the field, SICPA, ${ }^{65}{ }^{66}$ most notably the cost and lack of TTC control. $^{65}{ }^{66}$ The TTCs' strategy appeared to involve three key elements: to collectively develop their own alternative, Codentify (box 1), and promote it to governments as a digital tax verification (DTV) and T\&T system ${ }^{65^{671}}$; to actively oppose tax stamp systems and convince governments they were inferior to Codentify ${ }^{66}{ }^{671}$; and to 'proactively shape T\&T regulation ${ }^{66}$ to enable the above. ${ }^{66}$ BAT Whistleblower Paul Hopkins' Employment Tribunal documents allege that he was tasked by the company's lead for Anti-Illicit Trade 'to disrupt and if possible stop other service providers of DTV and T\&T products from winning tenders ...[because].... BAT had developed its own preferred system in conjunction with Philip Morris International called Codentify and wanted this system to be adopted by as many countries as possible. ${ }^{72}$

Engaging governments and tax authorities in order to promote common standards on T\&T that would help secure the implementation of Codentify over tax stamps appear to have been key ${ }^{6571}$ Documents note, for example, that: 'Manufacturers should be involved in providing advice and assistance on best practice solutions to governments intending to institute new systems and, where appropriate, should participate in the drafting process, for example in relation to any proposed Framework Convention on Tobacco Control (FCTC) Illicit Trade Protocol'. ${ }^{69}$

The TTCs closely monitored ITP negotiations ${ }^{73}$ and, despite being formally excluded, BAT was, at different stages, able to obtain confidential information ${ }^{745}$ apparently including the text of the protocol. ${ }^{76}$ A 45 -page document setting out BAT's campaign plan for the fifth Conference of the Parties in November 2012, where the ITP was adopted, noted BAT's preferred outcome on T\&T as 'Stamping and coding should be digital (Codentify). ${ }^{, 71}$

\section{Developing Codentify as a pan-industry product}

Codentify was originally patented by PMI in the mid-2000s following its legal agreement with the $\mathrm{EU}^{77}$ (see Timeline in table 1). In late 2010, 2 years after ITP negotiations had begun, PMI licensed Codentify for free to the other TTCs who collectively established a Working Group to collaborate on 'DTV', ${ }^{65} 67$ promoting Codentify to governments as an alternative to tax stamps. ${ }^{67}$

\section{Promoting Codentify via an increasingly elaborate set of front groups}

In line with the ITP specification that T\&T systems cannot be 'delegated to the tobacco industry, ${ }^{78}$ the pan-industry agreement and linked documentation stipulated the importance of making Codentify appear independent. ${ }^{657}$ This need was later underscored when BAT noted that the South African Department of Health "voiced its concern and will not support an "Industry" solution. ${ }^{66}$ The TTCs therefore began giving the impression of independence via a complex system of front groups and third parties.

\section{Digital Coding and Tracking Association}

The first of these front groups, the Digital Coding and Tracking Association (DCTA), was created by the TTCs in 2011 to promote Codentify to governments, ${ }^{679}$ a role it continues to perform. ${ }^{80}{ }^{81}$ DCTA's glossy brochure claimed Codentify could 'meet the expected licensing provisions of [ITP] Article 5' and deliver 'Full Government control' but failed to acknowledge it was developed and patented by the tobacco industry. ${ }^{82}$ It has promoted Codentify in a recent consultation, again failing to acknowledge industry links. ${ }^{83}$

\section{FractureCode and ATOS}

The pan-industry agreement also outlined the role for 'an independent reputable organisation' to promote Codentify:

When discussing DTV with authorities, it is important to stress that while the solution is developed and supported by the major industry players, the operation and control of the system will be handled by an independent reputable organization assigned by the respective government. ${ }^{6567}$

Documentation outlines that this was necessary because governments 'need to be convinced for themselves that this [Codentify] is a high quality solution, which works totally under their control and supervision, and which is supplied to them by a credible third party technology company. ${ }^{65}$

Yet simultaneously it suggests that TTCs (rather than governments) would select these 'independent' organisations and had already pre-selected two-FractureCode and Siemens. ${ }^{65}$ Their role was to: "guarantee to governments that the "Codentify" system works'; 'promote and sell the system to governments'; and 'after winning a government tender... install the system' ${ }^{65} \mathrm{~A}$ later (2012) BAT email indicates that it was working 'globally with two approved suppliers to represent Codentify,' this time naming FractureCode and ATOS, ${ }^{84}$ both of which subsequently appear to have been involved in tendering for T\&T systems on the TTCs' behalf (see below). We identified no further evidence of Siemens fulfilling this role. However, Siemens is a longstanding supplier of tobacco manufacturing machinery, produces its own code reading systems ${ }^{85}$ and was reported to be involved in operationalising a T\&T system for BAT in Poland, providing both hardware (a code reading system) and software. ${ }^{86}$ Moreover, ATOS was involved in developing Codentify ${ }^{88}$ and in December 2010 acquired Siemens' IT services division for $€ 850$ million. ${ }^{89}$

FractureCode, a Danish company established in 2002, offers $\mathrm{T} \& \mathrm{~T}$, digital authentication and volume verification solutions including Codentify. ${ }^{90}$ Its web page claimed that Codentify is 'Aligned with expected requirements of WHO FCTC Protocol on Illicit Trade in Tobacco Products'. ${ }^{11}$ Although the industry's exact relationship with FractureCode was unclear even to BAT staff, ${ }^{84}{ }^{92}$ interactions during a tender process in Kenya suggest a close relationship with and degree of control by BAT (box 4). BAT Whistleblower Paul Hopkins' Employment Tribunal documents state that by 2011 FractureCode was 'in the pay' of BAT. ${ }^{72}$ As the first T\&T system to be implemented in Africa post-ITP, Kenya's tender outcome would have significant ramifications, making BAT fearful that SICPA's product would be approved..$^{93}$ Documents suggest that FractureCode was also representing Codentify in Mauritius, Uganda and possibly Germany. ${ }^{84} 92$

French company, ATOS, originally involved in Codentify's development ${ }^{87} 88$ and named in leaked BAT documents ${ }^{84}$ may have played a similar role to FractureCode. It has promoted Codentify in Asia ${ }^{94}$ and been involved in the implementation of Codentify in Lithuania alongisde DCTA. ${ }^{95-98}$ 
Box 4 Links between British American Tobacco (BAT) and FractureCode illustrated by the tender process for a track and trace (T\&T) system in Kenya

In 2012, Kenya held a tender for tobacco revenue stamps with T\&T and integrated product accounting systems. BAT did not tender for the service directly but instead used FractureCode to promote Codentify. As Eric Jones, BAT's International Solutions Engagement Manager for Global Supply Chain Tracking and Verification, noted: "following the launch by the KRA [Kenyan Revenue Authority] of the tender that clearly favoured SICPA, we agreed the use of FractureCode (FCC) to support you [BAT Kenya] in fighting/amending/cancelling this tender." He added: "It is worth noting that not using a third party such as FCC to respond to the tender is likely to severely reduce our ability to shape events and prevent SICPA from winning". ${ }^{93}$

Other emails note that BAT had 'purchased' the tender on FractureCode's behalf, ${ }^{921}$ organised a consultant to represent them [FractureCode]' at a KRA question and answer session and drafted a letter on FractureCode's behalf..$^{92}$ It appears this letter was to be sent by FractureCode to the Commissioner General of the KRA, saying: "We, FractureCode Corporation/Codentify, a well established Security Company in Denmark, promoting and selling Digital Tax Verification for Tobacco and Alcohol Products, would like to formally protest about the conduct of the recent KRA tender carried out by your authority." 222 Other documents suggest BAT wrote the original draft. ${ }^{223}$

BAT also required FractureCode to 'Work with the Danish Embassy/Foreign Affairs to get tender cancelled. (This borne by FCC). ${ }^{184}$ Documents indicate that the Danish Embassy wrote a letter on FractureCode's behalf and met with the KRA to help get the tender extended. ${ }^{224}$ On 4 May 2012, a Danish Embassy staff member in Nairobi emailed the minutes of their meeting with the KRA to FractureCode stating: "We believe the result of this meeting leaves room for your company to submit your bid and have a direct dialogue with the KRA throughout the process. The Embassy would be happy to assist you in facilitating the contract." ${ }^{225}$ The Embassy sent FractureCode an invoice for 9 hours work at $\mathrm{Kr} 915$ (Danish Kroner) an hour. ${ }^{225}$ It is not known whether the KRA and Embassy understood the BAT link.

Despite these efforts, at the end of 2012, KRA awarded the tender to SICPA. ${ }^{189}$ The subsequent implementation of the T\&T system was completed by March 2014 and government figures indicate a $49 \%$ increase in legal cigarette and cigar sales and a $20 \%$ increase in tobacco tax revenue from 2013 to $2015{ }^{167}$

\section{Inexto}

The outing of DCTA as a tobacco industry front group in $2012^{17}$ limited the TTCs' ability to argue that Codentify was independent. With efforts to operationalise the ITP accelerating, this was becoming increasingly important. ${ }^{17}$

On 24 June 2016, the EU became the 19th party to ratify the ITP. ${ }^{99}$ Three weeks before, DCTA announced it had sold Codentify to a company called Inexto, an affiliate of the French Group Impala, ${ }^{100}{ }^{101}$ reportedly for only 1 Swiss Frank. ${ }^{102-104}$ Inexto had been established just a few weeks previously ${ }^{101}$ and when the handover was reported in the press, a PMI spokesperson claimed Codentify "now complies with ... the WHO's Framework Convention on Tobacco Control."105

Yet Inexto's links to PMI are clear. Its managing director is Philippe Chatelain, previously PMI's Director of Product Tracking Intelligence \& Security for 14 years. ${ }^{105} 106$ Other top officials are Erwan Fradet, PMI's Product Manager for Codentify for $5 \frac{1}{2}$ years, ${ }^{107}$ and Patrick Chanez, who worked for PMI for over 10 years developing anti-illicit trade technology. ${ }^{108}$ All three are coinventors of Codentify and still (as of November 2017) hold numerous patents with various PMI companies although now also hold some with Inexto and one with DCTA (Espacenet search 13 November 2017). Four months after the June 2016 announcement, Philip Morris Products SA still owned the global trademark rights to Codentify (online supplementary appendix 2, figure 1a) and Chatelain still held signing authority for that company (this ended 3 November 2016). ${ }^{109}$

Following public criticism of the close link between PMI and Inexto, ${ }^{105} 110111$ two of the trademarks for Codentify, covering Switzerland and the EU member states (online supplementary appendix 2 , figure $1 \mathrm{~b}$ ), were transferred to Inexto in late November 2016. ${ }^{112-114}$ Chatelain has since suggested that the Codentify system has been redeveloped from scratch, again publicly implying it would be compliant with the ITP. ${ }^{81}$ Yet, an additional 20 Codentify trademarks in the WIPO database are still listed as being held by PMI companies covering, for example, Chile, USA, Indonesia, Israel, Mexico, Malaysia, Jordan and UAE, some with application dates as recent as March 2017. ${ }^{115}$ Nevertheless, in June 2018 PMI stated to the Guardian newspaper: "We confirm that the worldwide assignment of all Codentify trademarks, previously owned by Philip Morris Products SA, to Inexto SA (part of Impala Security Solutions B.V.) was completed. It is up to Inexto SA to take steps to record the change of ownership at all relevant trademark registries, including WIPO.”

\section{The Coalition Against Illicit Trade (CAIT)}

The latest group promoting 'an industry operated solution'116 is the CAIT (figure 1), formed in June 2015 (3 months after the EU T\&T feasibility assessment was published $)^{117}$ and described as 'a new worldwide coalition of businesses and organisations dedicated to fighting the trade of counterfeited and contraband goods'. ${ }^{118}$ As of November 2017, six of the seven members (an eighth, Aegate, has gone into administration ${ }^{119}$ ) can be linked to the tobacco industry. Yet its submissions to the EU T\&T consultation ${ }^{116}$ and EU transparency register ${ }^{120}$ fail to mention tobacco industry links.

ATOS and FractureCode (see previous section) are members ${ }^{121}$ as is Inexto's sister company within the Impala Group, Arjo Solutions. ${ }^{121} 122$ Of the other three, FATA Logistics was associated with the development and promotion of Codentify. ${ }^{123}$ Domino, a printing and technology company, ${ }^{124}$ claims to have worked closely with the Codentify development team and the tobacco industry for over a decade. ${ }^{125}$ Describing itself as a global provider of Codentify ${ }^{126}$ and the 'tobacco industry's coding technology supplier of choice ${ }^{, 127}$ it is involved in a project to adapt Codentify to pharmaceuticals. ${ }^{128}$ Essentra, which produces cigarette filters and packaging (including security solutions such as holographic products and specialist inks), has been working with the tobacco industry for 65 years. ${ }^{129} 130$

\section{Engaging regulatory agencies and enhancing public relations efforts}

A 2012 BAT presentation identified 'key influencer stakeholder groups' as central to 'proactively shap[ing]Track and Trace regulation'. Listed stakeholders included the World Customs Organization (WCO), International Monetary Fund, Interpol and Organisation for Economic Cooperation and Development (OECD) alongside 'Key influencer' governments. ${ }^{66}$ Evidence 

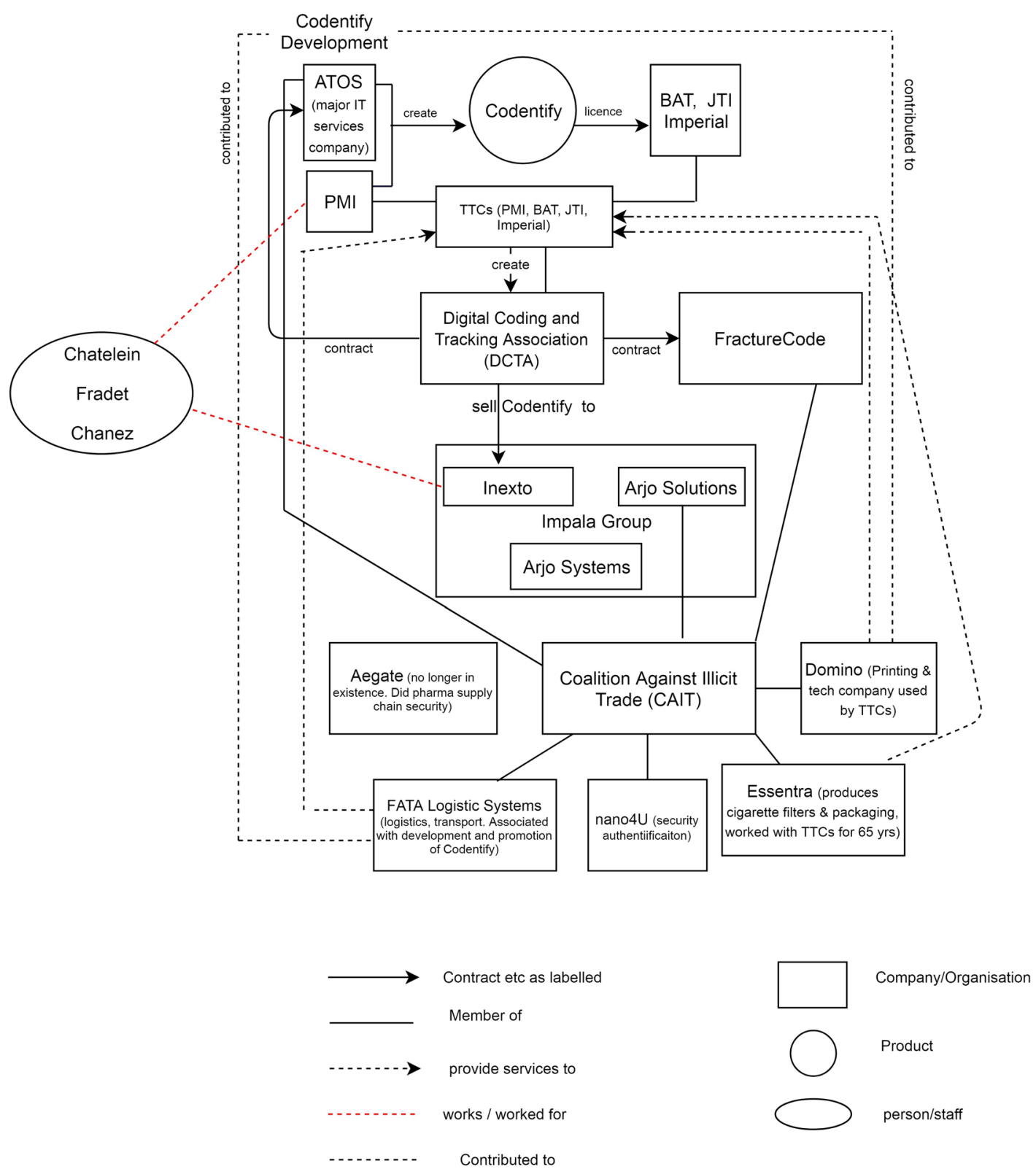

Figure 1 Diagram showing relationships between the creators and promoter of Codentify and the TTCs. BAT, British American Tobacco; JTI, Japan Tobacco International; PMI, Philip Morris International; TTCs, transnational tobacco companies.

suggests such efforts have been extensively operationalised creating a powerful network that promotes the TTCs' position on illicit.

In 2011, PMI donated $€ 55000$ to the International Anti-Corruption Academy, an organisation initiated by the European Antifraud Office (OLAF) and UN Office on Drugs and Crime (UNODC) to provide anti-corruption education and research. ${ }^{131}$

In 2012, PMI donated $€ 15$ million to Interpol, the world's largest police organisation, to work with DCTA to promote Codentify. ${ }^{79}$ It made Codentify accessible to law enforcement agencies via Interpol's Global Register ${ }^{79} 132133$ and Interpol's then Secretary General publicly promoted it. ${ }^{134}$ BAT's Eric Jones outlined the importance of Interpol's involvement stating it "will reinforce the credibility of the DCTA (and BAT) when talking to Governments as a credible provider of technology on DTV and T\&T."135
BAT flagged cooperation with WCO as important because of the 'need for cross border/regional solutions shaped by WCO not WHO. ${ }^{68}$ In 2014, the industry's DCTA was a major sponsor of the WCO conference on illicit tobacco in Brisbane, Australia. KPMG's Robin Cartwright presented in DCTA's time slot and, despite then taking $£ 10$ million a year from PMI, ${ }^{6136}$ failed to acknowledge this in his slides. ${ }^{137}$ Simultaneously, KPMG and GS1 UK launched a new report promoting Codentify ${ }^{138}$ which mentioned DCTA funding but not DCTA's tobacco industry status. $^{6}$ WCO also works closely with Interpol $^{139}$ and other tobacco industry-linked groups, including the International Tax and Investment Centre, ${ }^{140} 141$ with whom WCO has cohosted conferences and training on tobacco smuggling. ${ }^{142-144}$

The International Chamber of Commerce has close links to and has repeatedly supported the tobacco industry. ${ }^{140}$ All four TTCs are members of its Business Action to Stop Counterfeiting and 
Piracy (BASCAP) initiative which purports to 'combat product counterfeiting'. ${ }^{140} 145$ Through events which BASCAP organises or participates in, including an August 2016 UN Counter-Terrorism Centre meeting, TTCs are given a platform to present their position on illicit trade, counterfeiting and crime. ${ }^{140} 146-149$

In addition to these international efforts, TTCs have been working with national Governments ${ }^{3}$ and via ex-policemen and front groups established by or representing policemen ${ }^{150-155}$; BAT describing them as 'the credible voice for contraband tobacco'. 156

In 2016, PMI launched PMI Impact with \$100 million to fund projects addressing illicit trade, corruption, organised crime and money laundering. ${ }^{157}$ With applications judged by an Expert Council of individuals closely linked to multiple UN agencies $^{158}$ and Interpol, ${ }^{159}$ and PMI Impact's September 2017 event featuring presentations from (and enabling PMI executives to link with), among others, WCO, OECD, Europol and numerous UN agencies including the UNODC (see second paragraph in this section), it would appear the initiative's purpose is to further cement PMI's access to authorities and undermine the WHO and the FCTC Secretariat among UN agencies. The first 32 recipients of funding (totalling approximately US\$28 million) announced in September $2017^{160}$ include KPMG, Oxford Economics, Transcrime and others previously commissioned by PMI to produce widely criticised reports ${ }^{2025161162}$ on illicit favourable to the TTCs. ${ }^{159} 161162$

\section{DISCUSSION}

This evidence outlined in this paper indicates that the tobacco industry has created a T\&T system it can control and, through an elaborate campaign involving front groups, third parties and increasingly complex relationships with other companies, all underpinned by a massive public relations effort, is aiming to have this system implemented as the global T\&T system of choice under the ITP. Simultaneous evidence suggests it remains involved in tobacco smuggling. This combination of events would fundamentally undermine the ITP by enabling tobacco companies, with a vested interest in minimising their tax payments, to control the very system aimed to maximise those payments and reduce tobacco smuggling.

Three key findings underpin this conclusion. First, diverse and growing evidence shows that tobacco industry illicit outstrips the problems of cheap whites and counterfeits and remains the single largest problem in illicit tobacco; that incentives for industry involvement have barely changed since their well-documented involvement in the 1990s; that tobacco companies likely continue to be involved in and benefit from tobacco smuggling; and that this problem has persisted since the widespread introduction of Codentify. Possible interpretations are that Codentify is technically unfit for purpose or that TTC control renders Codentify useless.

Second, TTCs have a vested interest in controlling a T\&T system intended to address tobacco industry illicit and fear T\&T systems outside their control. This drove them to work collaboratively to oppose competitor systems, promote their own digital system, Codentify, and influence regulation on T\&T to favour it. This collaborative campaign involved extensive subterfuge including the creation of front groups like DCTA to promote Codentify and channel funding to others who further promoted Codentify (eg, KPMG and WCO), and use of companies like FractureCode. Later elements of their intellectual property on Codentify were sold to other companies with Codentify now being promoted by companies and coalitions purporting to be independent yet having clear TTC links, including co-ownership of intellectual property rights to Codentify by former PM staff now at Inexto.

Third, underpinning all the above, was an extensive and wellfunded stakeholder management and public relations effort involving funding for conferences, training, research, ex-policemen to act as spokespeople, and major organisations in the field including intergovernmental organisations. Such efforts are often operationalised via third parties (eg, DCTA, BASCAP) or specific initiatives (eg, PMI Impact). They serve to: cement the TTCs' previously observed control over data and research on tobacco smuggling ${ }^{6}$; create and disseminate discourses favourable to industry; and build a network of influential organisations and individuals that support, promote and enhance the credibility of these misleading industry discourses. These efforts should be seen as part of a broader strategy to rehabilitate the TTCs' image, ${ }^{163-165}$ reintegrate TTCs into policy-making circles from which they have been excluded, and undermine WHO and the Convention Secretariat among UN agencies. The concern that such efforts lead to regulatory capture is enhanced by findings from Africa that BAT has been paying to obtain data suggesting its competitors were smuggling and to gain influence with tax authorities.

What this paper adds

What is already known on this subject

- The Framework Convention on Tobacco Control's Illicit Trade Protocol (ITP) aims, inter alia, to secure the supply chain of legally manufactured tobacco products through a global track and trace (T\&T) system. Given evidence of the tobacco industry's (TI) historical involvement in cigarette smuggling, the protocol stipulates that such systems 'shall not be performed by or delegated to the tobacco industry'. Philip Morris International developed a code-generating system, Codentify, and licensed it for free to its competitors in a deal which saw the four transnational tobacco companies agree to promote Codentify to governments as a T\&T system.

What this paper adds

- Growing evidence indicates the TI remains involved in tobacco smuggling and therefore has a vested interest in controlling any T\&T system aimed to control its supply in order to avoid scrutiny and minimise its excise payments.

- The TI's attempts to have its Codentify-based system implemented as a T\&T system have become increasingly underhand. They include claiming Codentify is independent of the TI by using front groups and front companies to promote it; selling some parts of its intellectual property on Codentify while retaining others, leaving a complex web of shared interests; paying networks of spies to obtain data showing its competitors are smuggling; and providing significant funding (administered directly and via third parties) for conferences, training, research and international police and anti-corruption organisations which serves to foment confusion over tobacco smuggling and create a powerful network supportive of the TI's position.

- Governments should assume that any system based on Codentify, on intellectual property currently or previously owned by the $\mathrm{Tl}$, or being promoted by companies with $\mathrm{TI}$ links, is incompatible with the ITP and would not serve to reduce illicit trade within the legal supply chain. 


\section{Limitations}

Like any illegal activity, tobacco smuggling is complex, hidden and hard to investigate. We are limited to data that are publicly available and documents provided to us and cannot, therefore, access legal agreements between TTCs, DCTA and the various companies now promoting Codentify.

\section{Policy implications}

The findings signal a very real danger of regulatory capture of the governmental and intergovernmental institutions responsible for addressing tax evasion and TTCs coming to control a global T\&T system thereby fundamentally undermining it. Recent press reports from Argentina suggest these dangers may already be being realised with legal charges against PMI alleging its use of Codentify to hide levels of cigarette production in order to avoid paying taxes. ${ }^{166}$ By contrast we note the increase in legal tobacco sales and tobacco tax revenue in Kenya postimplementation of an independent T\&T system (box 4). ${ }^{167}$

The findings indicate that determining independence from industry when operationalising the ITP is increasingly difficult. Experience in the $\mathrm{EU}^{168}$ suggests that definitions which require countries, possibly repeatedly, to search patent and trademark registers, investigate industry links and company sources of income, and so on, are best avoided.

We therefore suggest, broadly in line with Convention Secretariat recommendations, ${ }^{169}$ that governments should be alert to the likelihood that TTCs will continue to disguise their links to Codentify and that Codentify will be promoted under different names and by different companies. The safest response is for governments to assume that (1) the TTCs remain involved in any T\&T system based on Codentify or on intellectual property currently or previously owned by a TTC and (2) such a system would be incompatible with the ITP and ineffective in reducing illicit trade within the legal supply chain. The industry's own use of Codentify to help address counterfeiting should be seen as entirely separate. To help address potential regulatory capture, decisions on T\&T should be cross-governmental and it is vital that health ministries are involved.

\begin{abstract}
Acknowledgements We thank Deborah Arnott, Emmanuelle Beguinot, Nijole Goštautaite Midttun, Professor Jonathan Griffiths (Queen Mary, University of London), Luk Joossens and Dr Hana Ross (University of Cape Town) for comments on the paper and/or background information. Any mistakes are entirely the authors' own.

Contributors $A B G$ conceived the idea for the study, undertook the data analysis and drafted the first version. $A B G$ and $A R$ investigated trademark ownership and $A B G$ and $A W A G$ produced timeline. ABG, AR, AWAG all contributed to document analysis, investigation of third parties and patent ownership, and editing of paper.
\end{abstract}

Funding This work was supported by Cancer Research UK (www.cancerresearchuk. org) (grant no: C27260/A20488). Some of the documents used in this analysis were obtained as a result of research funded by the New Venture Fund.

Disclaimer The opinions expressed are those of the authors' alone.

Competing interests None declared.

\section{Patient consent Not required.}

Provenance and peer review Not commissioned; externally peer reviewed.

Open access This is an open access article distributed in accordance with the terms of the Creative Commons Attribution (CC BY 4.0) license, which permits others to distribute, remix, adapt and build upon this work, for commercial use, provided the original work is properly cited. See: http://creativecommons.org/licenses/by/4.0/

(c) Article author(s) (or their employer(s) unless otherwise stated in the text of the article) 2019. All rights reserved. No commercial use is permitted unless otherwise expressly granted.

\section{REFERENCES}

1 World Health Organization. Protocol to eliminate illicit trade in tobacco products. $2013 \mathrm{http}: / / w w w . w h o . i n t / f c t c / p r o t o c o l / i l l i c i t$ trade/protocol-publication/en/ (accessed 21 Jan 2018).

2 Joossens L, Raw M. Cigarette smuggling in Europe: who really benefits? Tob Control 1998; 7:66-71.

3 Fctc WHO, Bialous S. The Tobacco Industry and the Illicit Trade in Tobacco products. http://www.who.int/fctc/publications/The-Tobacco-Industry-and-the-Illicit-Trade-inTobacco-Products.pdf.

4 Joossens L, Raw M. How can cigarette smuggling be reduced? BMJ 2000;321:947-50.

5 Nakkash R, Lee K. Smuggling as the "key to a combined market": British American Tobacco in Lebanon. Tob Control 2008;17:324-31.

6 Gilmore AB, Fooks G, Drope J, et al. Exposing and addressing tobacco industry conduct in low-income and middle-income countries. The Lancet 2015;385:1029-43.

7 Lee K, Collin J. "Key to the future": British American tobacco and cigarette smuggling in China. PLoS Med 2006:3:e228.

8 The International Consortium of Investigative Journalists. Global Reach of Tobacco Company's Involvement in Cigarette Smuggling Exposed in Company Papers. 2000 https://www.icij.org/investigations/big-tobacco-smuggling/global-reach-tobaccocompanys-involvement-cigarette-smuggling-exposed-company-papers/.

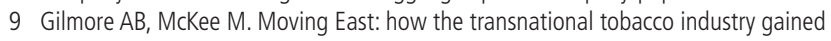
entry to the emerging markets of the former Soviet Union-part I: establishing cigarette imports. Tob Control 2004;13:143-50.

10 Collin J, Legresley E, MacKenzie R, et al. Complicity in contraband: British American Tobacco and cigarette smuggling in Asia. Tob Control 2004;13:ii104-11.

11 Home Affairs Committee. First Report - Tobacco Smuggling. https://publications. parliament.uk/pa/cm201415/cmselect/cmhaff/200/20002.htm (accessed $25 \mathrm{Jul}$ 2017).

12 Beltrame J, Fairclough G. Canada sues R.J. Reynolds Tobacco for \$1 billion, Alleges smuggling plot. https://www.wsj.com/articles/SB94579377624800941 (accessed 06 Nov 2017).

13 US District Court. THE EUROPEAN COMMUNITY, Plaintiff, v. RJR NABISCO, INC., et al., Defendants. DEPARTMENT OF AMAZONAS, et al., Plaintiffs, v. PHILIP MORRIS COMPANIES, INC., et al., Defendants. http://uniset.ca/other/cs6/150FSupp2d456. html (accessed 06 Nov 2017).

14 Hache T. Tobacco-Related Litigation in Canada. 2010 http://nsra-adnf.ca/wp-content/ uploads/2016/07/Tobacco-related_Litigation_in_Canada_2010.pdf (accessed 25 Jul 2017).

15 CBC News. Tobacco firms to pay $\$ 550 M$ over smuggling. http://www.cbc.ca/news/ canada/tobacco-firms-to-pay-550m-over-smuggling-1.902510 (accessed 25 Jul 2017).

16 Joossens L, Gilmore AB, Stoklosa M, et al. Assessment of the European Union's illicit trade agreements with the four major Transnational Tobacco Companies. Tob Control 2016;25:254-60.

17 Joossens L, Raw M. From cigarette smuggling to illicit tobacco trade. Tob Control 2012;21:230-4

18 European Commission. Action plan to fight against smuggling of cigarettes and alcohol along the EU Eastern border. Commission staff working document accompanying the communication on the Commission anti-fraud strategy. http://aei. pitt.edu/45825/1/SEC_(2011)_791.pdf (accessed 06 Nov 2017).

19 Ulucanlar S, Fooks GJ, Gilmore AB. The policy dystopia model: an interpretive analysis of tobacco industry political activity. PLoS Med 2016;13:e1002125.

20 Chen J, McGhee SM, Townsend J, et al. Did the tobacco industry inflate estimates of illicit cigarette consumption in Asia? An empirical analysis. Tob Control 2015;24(e2) :e161-7.

21 Philip Morris International. Philip Morris International: New study finds EU black market for cigarettes reaches record high; Member State tax loss an estimated $€ 12.5$ billion. 17 Apr 2013. http://www.businesswire.com/news/home/20130417005543/ en/Philip-Morris-International-New-Study-Finds-EU (accessed 06 Nov 2017).

22 Philip Morris International. KPMG Sun Report: One in Ten Cigarettes Consumed in the EU in 2012 Were Illegal; Dramatic Rise in Consumption of 'Illicit Whites'. http:// www.webcitation.org/6qA62KsQm (accessed 02 Apr 2017).

23 Lee B. Digital Coding and Tracking Association. Effective decision making empowered by technology. http://iticnet.org/file/document/watch/4487 (accessed 03 Oct 2017).

24 Smith KE, Savell E, Gilmore AB. What is known about tobacco industry efforts to influence tobacco tax? A systematic review of empirical studies. Tob Control 2013;22:e1-153.

25 Gilmore AB, Rowell A, Gallus $\mathrm{S}$, et al. Towards a greater understanding of the illicit tobacco trade in Europe: a review of the PMI funded 'Project Star' report. Tob Control 2014;23(e1):e51-61.

26 Parliament E. European Parliament's Committee on Budgetary Control. Workshop "Cigarette Smuggling" Proceedings. 2014 http://www.europarl.europa.eu/ document/activities/cont/201401/20140116ATT77675/20140116ATT77675EN.pdf (accessed 4 Jul 2014). 
27 MacGregor J. Operation Henry 2 "OH2": a coordinated operation to tackle the supply of illicit tobacco in England. Commissioned by the Department of Health Tobacco Policy Team. https://www.tradingstandards.uk/media/documents/newspolicy/tobacco-control/oh2-final-version-august-15.compressedamended.pdf (accessed $10 \mathrm{Jul}$ 2017).

28 Holland J, Jovanovic B, Dojcinovic S. Big trouble at Big Tobacco. 2011 http://www. reportingproject.net/troubles_with_big_tobacco/(accessed 18 Nov 2011).

29 Lavrov V. Ukraine's 'Lost' Cigarettes Flood Europe. Big tobacco's overproduction fuels $\$ 2$ billion black market. 2009 https://www.icij.org/investigations/tobaccounderground/ukraines-lost-cigarettes-flood-europe/ (accessed 06 Nov 2017).

30 Pauw J. Chapter 8: Tom's Tempest, Chapter 10: Up in Smoke. The President's Keepers -Those keeping Zuma in power and out of prison: Tafelberg, 2017.

31 Public Accounts Committee. HM revenue \& customs: progress in tackling tobacco smuggling: summary. https://publications.parliament.uk/pa/cm201314/cmselect/ cmpubacc/297/29703.htm (accessed 1 Jan 2017).

32 Report by the Comptroller and Auditor General. Progress in Tackling Tobacco Smuggling. https://www.nao.org.uk/wp-content/uploads/2013/06/10120-001Tobacco-smuggling-Full-report.pdf (accessed 06 Nov 2017).

33 Loggerenberg J, Lackey A. Chapter 11. Project Honey Badger. Rogue The inside story of SARS' elite crime-busting unit. Jeppestown: Jonathan Ball Publishers, 2016.

34 BBC News. HMRC fines cigarette maker for oversupplying Belgium. http://www.bbc co.uk/news/business-30038328 (accessed 5 Jan 2017).

35 Monckton Chambers. British-American Tobacco Ltd v HMRC First-tier Tribunal (Tax Chamber), 14 February 2017; [2017] UKFTT 167 (TC): Tribunal clarifies tobacco manufacturers' anti-smuggling duties. https://www.monckton.com/british-americantobacco-ltd-v-hmrc-first-tier-tribunal-tax-chamber-14-february-2017-2017-ukftt167-tc-tribunal-clarifies-tobacco-manufacturers-anti-smuggling-duties/ (accessed 03 Oct 2017).

36 Mpezo N. AlT Management in DRC, AlT activities condensed. created in 2006.

37 Anon. BAT Customs and Excise Conference. Limissol, Cyprus: BAT, JTI/TCC Project, 2012

38 Gillard M. CANCER FOR CASH: Explosive Photo Exposes Big Tobacco's African Money Drops. https://newmatilda.com/2017/08/02/exclusive-where-theres-smokestheres-fire-and-lots-of-illegal-cash/ (accessed 10 Oct 2017).

39 Bosely S. Revealed: how British American Tobacco exploited war zones to sell cigarettes. https://www.theguardian.com/world/2017/aug/18/british-americantobacco-cigarettes-africa-middle-east (accessed 23 Nov 2017)

40 Atallah E. Subject: RE: RKS, Email to P. Hopkins.

41 Ramoly N. Subject: Re: RKS, Email to P. Hopkins.

42 Hopkins P. Email to N. Ramoly, Fw: RKS, 24 Jan 2012; BAT email, 11 Jan 2012; BAT email.

43 Sole S, Faull L. Big Tobacco in bed with SA law enforcement agencies. Mail \& Guardian. https://mg.co.za/article/2014-03-20-big-tobacco-in-bed-with-sa-lawenforcement-agencies (accessed 30 Jan 2018).

44 Rees M. BAT's smoke and mirrors war on rivals. Sunday Times. https://www. pressreader.com/south-africa/sunday-times/20140330/282299613130796 (accessed 30 Jan 2018)

45 Comrie S. SARS drama spills over into the UK. City Press. http://city-press.news24 com/Business/Sars-smokes-out-big-tobacco-20150516 (accessed 30 Jan 2018).

46 Bailey C. Sars to clamp down on tobacco companies. Business Report. https://www. iol.co.za/business-report/companies/sars-to-clamp-down-on-tobacco-companies1611521 (accessed 30 Jan 2018).

47 Rees M. BAT's bid to stub out spy saga. Sunday Times. https://www.pressreader.com/ south-africa/sunday-times/20141116/282278138628618 (accessed 30 Jan 2018).

48 Thamm M. SARS Wars: Massive data leak alleges British American Tobacco SA's role in bribery and corruption. Daily Maverick. https://www.dailymaverick.co. za/article/2016-08-16-sars-wars-massive-data-leak-alleges-british-americantobacco-sas-role-in-bribery-and-corruption/ -. WnBXk105tTZ (accessed 30 Jan 2018)

49 Wainaina A. MTK review.

50 Hopkins P. Re: 2010 Exports Declaration of MM for Malawi and Zambia, 2010.

51 Kaleechurn K. Exports Declaration of MM for Malawi and Zambia, 2010.

52 Hopkins P. 2010 Exports Declaration of MM for Malawi and Zambia, 2011.

53 Duncan E. Re: Fwd: MM case in Todays people newspaper.

54 Hopkins P. Fwd: MM case in Todays people newspaper.

55 Hopkins P. Confidential info flash.

56 Hopkins P. [Email to World Bank staff] Fiscal Tax evasion in DRC, Uganda and Kenya.

57 Carnilinx R. (Pty) Limited and British American Tobacco Holdings. Founding Affidavit, Daniel Francois Van Der Westhuizen.

58 Confidential agreement: Final payment for services Mr Prash K. 8 July 2008.

59 Naik P. URA Investigations.

60 Resources provided to BAT 2008-2009.

61 BAT Service Provider. Report. 25 June 2013.

62 BAT Service Provider. Background. June 2013

63 Muyita S. Plaintiff's Witness Statement: The High Court of Uganda at Kampala Civil Suit no. 318 of 2013, Solomon Muyita (Plaintiff) Vs. British American Tobacco (U) LTD (Defendant). 14 July 2015.
64 Muyita S. Whistle-blowing on bribery incidents in Uganda. Annex 9: The High Court of Uganda at Kampala Civil Suit no. 318 of 2013, Solomon Muyita (Plaintiff) Vs. British American Tobacco (U) LTD (Defendant). 29 July 2013.

65 Hill M. Digital Tax Verification (DTV) Codentify, the industry standard, 2010

66 British American Tobacco. Supply Chain Tracking and Verification: EEMEA: Strategy Update. 18 Oct 2012.

67 British American Tobacco, Imperial Tobacco Limited, Philip Morris International. Memo announcement of Industry Working Group (IWG). Agreement on Digital Tax Verification (DTV). Nov 2010.

68 British American Tobacco. How does BAT manage the threat to its corporate reputation, HDM QBR. Nairobi, 2003. May 2003.

69 British American Tobacco. Securing the future, anti-illicit trade. undated.

70 British American Tobacco (Holdings) Limited. Illicit Trade: examining the problem and advocating solutions, 2010

71 British American Tobacco. FCTC COP5 Campaign. 2011 https://www. documentcloud.org/documents/3892759-2011-British-American-Tobacco-FCTCCOP5-Campaign.html (accessed 25 Sep 2017).

72 Hopkins P. British American Tobacco. Grounds of Claim, Employment Tribunal No R007281/12/58. 23 Jul 2014

73 Network for Accountability of Tobacco Transnationals. Corporate Accountability International. Smokescreen for smuggling: tobacco industry attempts to derail the illicit trade protocol. 2012. https://www.alliantienederlandrookvrij.nl/wp-content/ uploads/2012/docs/accijns/ENGLISH Smokescreen for Smuggling FINAL.pdf (accessed 25 Sep 2017).

74 British American Tobacco. FCTC AlT protocol status post-INB5, preliminary as of 04/04/2012, based on reports from delegates after conclusion of INB5 Meeting. Apr 2012.

75 Owino JA. For information and action; AIT protocol IWG1 analysis to support engagement. 8 Aug 2011.

76 British American Tobacco. AlT Protocol IWG1 Outcomes Analysis. 5 Aug 2011.

77 European Patent Office. Document made available under the Patent Cooperation Treaty (PCT). International application number: PCT/IB2005/003103. https:// register.epo.org/documentView? number=IB.2005003103.W\&documentld= id00000002615337 (accessed 22 Nov 2017).

78 World Health Organization. Conference of the parties intergovernmental negotiating body on a protocol on illicit trade in tobacco products: First session. Geneva: World Health Organization.

79 Joossens L, Gilmore AB. The transnational tobacco companies' strategy to promote Codentify, their inadequate tracking and tracing standard. Tob Control 2014;23(e1) :e3-6.

80 Aries Q, Panichi J. Brussels blocks big tobacco lobbying push. Politico. 2018 https:// www.politico.eu/article/commission-blocks-tobacco-lobbys-cigarette-repackagingbid-technology-business-politics-commission-debate/.

81 Teffer P. Cigarette tracking rules risk being derailed by lobbyists. https://euobserver com/health/138135 (accessed 10 Oct 2017).

82 Philip Morris International. Codentify: protecting Government revenues, securing the supply chain, fighting illicit trade (brochure), 2012

83 European Commission. Targeted stakeholder consultation on the implementation of an EU system for traceability and security features pursuant to Articles 15 and 16 of the Tobacco Products Directive 2014/40/EU. https://ec.europa.eu/health/sites/health/ files/tobacco/docs/2015_tpd_c057_en.pdf (accessed 22 Jan 2018).

84 Jones E. RE: FractureCode support for Kenya, 23 April 2012 and follow up email on 25 April 2012. Apr 2012.

85 Siemens. Industrial identification for sustainability efficient processes: Comprehensive portfolio of RFID and code reading systems for seamless transparency in every industry. $2011 \mathrm{https}: / /$ www.siemens.com/press/pool/de/ materials/industry/iia/2011-02-simatic-ident/brochure-industrial-identification-e.pdf (accessed 23 Nov 2017)

86 Siemens. Automatic identification ensures more security in the supply chain: British American Tobacco. 2010 http://www.webcitation.org/6uToAWSVh (accessed 25 Oct 2017).

87 Ross H. Measures to control illicit tobacco trade. https://tobacconomics.org/wpcontent/uploads/2015/05/Ross_Available_measures_05.28.15.pdf (accessed 07 Nov 2017).

88 Bate R. Smoking out illicit trade: how some policies intended to limit smoking drive illegal trade. https://www.aei.org/wp-content/uploads/2016/09/Smoking-out-illicittrade.pdf (accessed 29 Sep 2017).

89 Godet J. Atos-Siemens (sis) Sera Le. https://www.linformaticien.com/actualites/id/ 9802/atos-siemens-sis-sera-le-nouveau-champion-europeen.aspx (accessed 23 Nov 2017)

90 Fracturecode. website. https://fracturecode.com/ (accessed 19 Dec 2016).

91 Fracturecode. Codentify, the provision of digital solutions for revenue protection, executive presentation to the ministry of finance, 2011.

92 Hopkins P. Re: FractureCode support for Kenya. Apr 2012

93 Jones E. Eric Jones, KRA Tender, Email. 11 May 2012.

94 Lequenne E. Applying technology to combat illicit trade and protect excise revenues, Asia-Pacific Tax Forum (Presentation). 16 Nov 2011. 
95 DELFI. Siūlo pasitikrinti, ar nenusipirkote kontrabandinių cigarečių. https://www.delfi. It/verslas/verslas/siulo-pasitikrinti-ar-nenusipirkote-kontrabandiniu-cigareciu.d?id= 50615048 (accessed 08 Nov 2017).

96 Valstybine Mokesciu Inspekcija. Lietuva pirmoji ES pradeda naudoti skaitmeninę sistemą akcizinių prekių apskaitai. http://www.vmi.lt/cms/naujienos/-/asset_ publisher/Gizm3fjHUUgi/content/id/8637641 (accessed 08 Nov 2017).

97 Unknown. Cigarečių unikalių kodų autentifikavimo sistema. 2015 https://www. cigareciupatikra.It/public/Default.aspx (accessed 08 Nov 2017).

98 Publico M. Adjuntos Agregados a la Oferta, Anexo No. 3: Ficha Experiencia Empresa. 2017 http://www.mercadopublico.cl/BID/Modules/POPUPS/ViewBidAttachment. aspx?enc=9c\%2BfHgE\%2BSjBbo7bm\%2FQLtcjX7iLmnBy6wJfqT1jHMvILjdUvWMR 9ZupzeuRI3P\%2Bew0\%2BpGhiqCK3IH91LzMHfQmAKbQIWgcThOyMShd9sJydh\% 2B4bCzTyKuRvA5Jn12RwYiyclh2PvUZ4n\%2Be5MmloVKQ\%3D\%3D (accessed 25 Oct 2017).

99 Reconnaissance TSN. EU ratifies illicit trade protocol - what does this mean for tobacco industry deals and TPD. 2016 https://www.reconnaissance.net/tax-stampnews/issues/june-2016/ (accessed 19 Dec 2016).

100 Digital Coding and Tracking Association. Press Release - DCTA technology ownership transferred to Inexto an affiliate of Impala Group. 01 Jun 2016.

101 Moneyhouse. Inexto SA. 2016. https://www.moneyhouse.ch/en/company/inexto-sa2486501071 (accessed 19 Dec 2016).

102 International Tax Stamp Association. Why codentify can never work as a secure track and trace solution under the WHO FCTC protocol and EU tobacco products directive. 2018 https://www.tax-stamps.org/userfiles/files/ITSA Positioning Statement on Codentify.pdf (accessed 14 Nov 2017).

103 European Network for Smoking and Tobacco Prevention. The context of tobacco and illicit trade. http://ensp.org/wp-content/uploads/2017/07/Tobacco-track-and-trace. pdf (accessed 21 January 2018).

104 Montet D, Ray RC. Food Traceability and Authenticity: Analytical Techniques. New York: CRC Press, 2017.

105 Teffer P. Big Tobacco suspected of dodging EU anti-smuggling rules. 2016 https:// euobserver.com/economic/133899 (accessed 07 Nov 2017).

106 JUSTIA. Codentify patent. 2009 http://patents.justia.com/inventor/patrick-chanez (accessed 21 Jun 2016).

107 Linked-In. Erwan Fradet. 2016 https://www.linkedin.com/in/erwan-fradet-b156883 (accessed 28 Dec 2016).

108 Linked-In. Patrick Chanez. 2016 https://www.linkedin.com/in/patrick-chanez-353b04 (accessed 21 June 2016).

109 Registre du Commerce. Philip Morris Products S.A. (06 Oct 2017).

110 House of Commons Hansard. Christmas Adjournment: 3.48pm, Martyn Day (Linlithgow and East Falkirk) (SNP). https://hansard.parliament.uk/Commons/ 2016-12-20/debates/FF51202E-34FA-48C7-B002-28DB6AF473AA ChristmasAdjournment - contribution-2494C922-BC37-458E-A0E8-246FC3551B09 (accessed 25 Sep 2017).

111 Bosely S. Anti-smuggling proposal 'may let tobacco industry in by back door'. https:// www.theguardian.com/business/2017/sep/08/anti-smuggling-proposal-may-lettobacco-industry-in-by-back-door (accessed 25 Sep 2017).

112 Swiss Federal Institute of Intellectual Property. Trademark number P-548516. Codentify. https://www.swissreg.ch/srclient/faces/jsp/trademark/sr30.jsp (accessed 23 Nov 2017).

113 World intellectual Property Organization. Madrid Monitor: International Trademark, 917422- Codentify, Real-time status. 2017 http://www.wipo.int/madrid/monitor/en/ (accessed 23 Nov 2017).

114 TMview.. Search on Codentify. https://www.tmdn.org/tmview/welcome (accessed 19 Dec 2016).

115 World Intellectual Property Organization. Global brand database search: codentify. http://www.wipo.int/branddb/en/ (accessed 23 Nov 2017).

116 Coalition Against Illicit Trade. Response to Public consultation on the implementation of an EU system for traceability and security features pursuant to Articles 15 and 16 of the Tobacco Products Directive 2014/40/EU. 2016 https://ec.europa.eu/health/ tobacco/consultations/2016_traceability_security_features_en (accessed 04 Dec 2017).

117 European Commission. Analysis and feasibility assessment regarding EU systems for tracking and tracing of tobacco products and for security features: final Report. https://ec.europa.eu/health//sites/health/files/tobacco/docs/2015_tpd_tracking_ tracing_frep_en.pdf (accessed 23 Nov 2017).

118 Coalition Against Illicit Trade. Launch of Coalition Against Illicit Trade (CAIT) to fight global counterfeiting and smuggling. http://www.prnewswire.com/news-releases/ launch-of-coalition-against-illicit-trade-cait-to-fight-global-counterfeiting-andsmuggling-507799091.html (accessed 10 Oct 2017).

119 Companies House. Aegate limited. 2017 https://beta.companieshouse.gov.uk/ company/05089909/insolvency (accessed 04 Oct 2017).

120 EU Transparency Register. Coalition against illicit trade. http://ec.europa.eu/ transparencyregister/public/consultation/displaylobbyist.do?id=566884224169-59\& locale=en\&indexation=true (accessed 04 Dec 2017).

121 Coalition Against Illicit Trade. Members. http://www.coalitionagainstillicittrade.org/ about-us/founding-members/ (accessed 03 Oct 2017).
122 Impala. Impala - Arjo Solutions \& Inexto. 2016 http://www.impala-sas.com/en/ participations/arjo-solutions-inexto (accessed 29 Sep 2017).

123 II Sole 24 Ore. Ecco "Codentify": tecnologia per tracciabilità prodotti tabacco. http:// stream24.ilsole24ore.com/video/impresa-e-territori/ecco-34codentify34-tecnologiaper-tracciabilit224-prodotti-tabacco/20140916_video_11373156? refresh_ce=1 (accessed 04 Oct 2017).

124 Domino. Domino printing sciences plc. 2013. Available http://dominoprinting.com/ Corporate/Home.aspx (accessed 10 Oct 2017).

125 Domino.. Codentify \& DotCode: an overview of domino's experiance \& capability. http://dominoprinting.com/Global/en/DocumentLibrary/Codentify-DotCode-brochure. pdf (accessed 10 Oct 2017).

126 Domino. When tobacco manufacturers need a coding solution. https://www. slideshare.net/JamesCutforth/dominotobaccobrochurescreen (accessed 04 Oct 2017).

127 Domino. Printing on cigarette packs. https://www.domino-printing.com/en/ industries/tobacco/pack-soft/printing-on-cigarette-packs (accessed 04 Oct 2017).

128 Taylor P. Domino taps tobacco expertise to help pharma serialize. https://www. securingindustry.com/pharmaceuticals/domino-draws-on-tobacco-experience-tohelp-pharma-serialize/s40/a2762/ -. WdSzt90GMcl (accessed 04 Oct 2017).

129 Essentra.. The Complete Service. https://www.essentra.com/en/industries/tobacco (accessed 04 Oct 2017).

130 Essentra.. Essential solutions, delivered. Generic customer brochure. https://www. essentra.com/en/industries/tobacco - downloadpdf (accessed 09 Oct 2017).

131 International Anti-Corruption Academy (IACA). Philip Morris International Contributes 55,000 EUR. 2013 http://www.iaca.int/245-philip-morris-internationalcontributes-55-000-eur (accessed 01 Oct 2014)

132 Philip Morris International. Philip Morris International Provides 15 Million Euro Contribution to INTERPOL to Fight Trafficking in Illicit Goods. https://web.archive. org/web/20161112140956/http://www.pmi.com/eng/media_center/press_releases/ pages/201206210200.aspx (accessed 19 Dec 2016).

133 Interpol. Interpol Global Register Unveiled at Google Ideas INFO Summit.

134 Noble RK. Interpol: 7th global congress on combating counterfeiting and piracy: opening plenary address. file:///Users/aag68/Downloads/SG\%20Global\%20 Congress $\% 202013 \% 20$ accessed 22 Jan 2018).

135 Jones E. Codentify and interpol global register, Email.

136 KPMG. Robin cartwright. https://home.kpmg.com/xx/en/home/contacts/c/robincartwright.html (accessed 07 Nov 2017).

137 Cartwright R. Track and trace approaches in tobacco (Presentation), 2014.

138 KPMG. Track and trace approaches in tobacco. 2014.

139 Interpol. INTERPOL targets organized crime with global initiative against trafficking in illicit goods. https://www.interpol.int/News-and-media/News/2012/PR050 (accessed 22 Jan 2018).

140 Bialous S. Corporate accountability International. Article 5.3 and international tobacco industry interference. 2016 http://apps.who.int/fctc/implementation/ database/sites/implementation/files/documents/resources/web_Article5.3report_ Mar_2016_FINAL.pdf (accessed 7 Nov 2016).

141 Tobacco Control Research Group. International tax and investment center. TobaccoTactics.org: University of Bath. http://www.tobaccotactics.org/index.php/ International_Tax_and_Investment_Center (accessed 29 Sep 2017).

142 International Tax and Investment Center. The illicit trade in tobacco products and how to tackle it: second edition. $2013 \mathrm{https}$ ://illicittrade.com/reports/downloads/ITIC - Illicit Trade in Tobacco Products booklet - 2nd edition Sept. 2013.pdf (accessed 29 Sep 2017)

143 Clear the Air. The International Tax and Investment Center (ITIC) - modern day equivalent of 30-pieces-of-silver promises its sponsors a seat at the Government policymaking tables - contrary to Article 5.3? 2015 http://tobacco.cleartheair.org. hk/wp-content/uploads/2015/10/InternationalTaxInvestmentCenter-updated.pdf (accessed 29 Sep 2017).

144 International Tax and Investment Center. WCO Knowledge Academy 2015 Excisable Products and Illicit Trade Module By Elizabeth Allen, Program Advisor, ITIC. http://iticnet.org/news-item/wco-knowledge-academy-2015-excisable-products-andillicit-trade-module (accessed 29 Sep 2017)

145 Tobacco Control Research Group. International chamber of commerce. TobaccoTactics.org.. http://tobaccotactics.org/index.php?title=International_ Chamber_of_Commerce (accessed 22 Jan 2018).

146 International Chamber of Commerce. The International Chamber of Commerce (ICC)'s Business Action to Stop Counterfeiting and Piracy (BASCAP) addressed United Nations (UN) delegates on how the trade in counterfeit and pirated goods helps to finance organized crime and terrorism. https://iccwbo.org/media-wall/newsspeeches/iccs-bascap-highlights-link-between-counterfeiting-and-terrorism-at-theunited-nations/ (accessed 22 Jan 2018).

147 International Chamber of Commerce. BASCAP: Intermediaries play crucial role to protect supply chains from counterfeiting and piracy. https://iccwbo.org/media-wall/ news-speeches/bascap-intermediaries-play-crucial-role-to-protect-supply-chainsfrom-counterfeiting-and-piracy/ (accessed 22 Jan 2018).

148 International Chamber of Commerce. Rights holders and intermediaries talk solutions to counterfeiting and piracy at ICC BASCAP-INTA workshop. https:// iccwbo.org/media-wall/news-speeches/rights-holders-and-intermediaries-talk- 
solutions-to-counterfeiting-and-piracy-at-icc-bascap-inta-workshop/ (accessed 22 Jan 2018).

149 International Trademark Association, International Chamber of Commerce. INTA-BASCAP workshop program. https://www.inta.org/Programs/Pages/ 2016BASCAPSingapore_Agenda.aspx (accessed 22 Jan 2018).

150 Sheridan P. Letter to tobacco programme manager, UK Department for Health. https://www.gov.uk/government/uploads/system/uploads/attachment_data/file/ 200223/Sheridan_-_6.pdf (accessed 25 Aug 2017).

151 Doward J. Plain packaging lobbyists under fire over links to tobacco company. The Observer 2013;28.

152 O'Reilly W. Tobacco Control Research Group. TobaccoTactics.org: University of Bath. http://tobaccotactics.org/index.php/Will_0\%E2\%80\%99Reilly (accessed 07 Nov 2017).

153 Evans-Reeves KA, Hatchard JL, Rowell A, et al. Content analysis of tobacco industry data on the illicit tobacco trade in UK newspapers during the standardised packaging debate. The Lancet 2016;388(Suppl 2):S6.

154 Tobacco Control Research Group. Third party techniques. TobaccoTactics.org: University of Bath. http://tobaccotactics.org/index.php/Third_Party_Techniques (accessed 06 Nov 2017).

155 Tobacco Control Research Group. The common sense alliance. TobaccoTactics.org: University of Bath. http://tobaccotactics.org/index.php?title=The_Common_Sense_ Alliance (accessed 10 Oct 2017).

156 Imperial Tobacco Canada. CORA AIT strategy: raising public awareness \& demanding government action, 2012

157 Philip Morris International. ABout PMI impact. http://www.pmi-impact.com/Explore/ About (accessed 25 Sep 2017)

158 Philip Morris International. PMI impact: expert council. http://www.pmi-impact.com/ Apply/Expert (accessed 03 March 2016).

159 Tobacco Control Research Group. PMI IMPACT. TobaccoTactics.org:University of Bath. http://www.tobaccotactics.org/index.php?title=PMI_IMPACT (accessed 06 Nov 2017).

160 Philip Morris International. Philip morris international announces first round of projects to be funded through pmi impact, a USD 100 million global initiative to fight illegal trade. http://www.webcitation.org/6tOhUb7LA (accessed 06 Nov 2017).

161 Tobacco Control Research Group. KPMG. TobaccoTactics.org: University of Bath. http://www.tobaccotactics.org/index.php?title=KPMG (accessed 06 Nov 2017).

162 Tobacco Control Research Group. Oxford economics. TobaccoTactics.org:University of Bath. http://www.tobaccotactics.org/index.php?title=0xford_Economics (accessed 06 Nov 2017).

163 Fooks G, Gilmore A, Collin J, et al. The limits of corporate social responsibility: techniques of neutralization, stakeholder management and political CSR. J Bus Ethics 2013 112:283 99

164 Fooks GJ, Gilmore AB, Smith KE, et al. Corporate social responsibility and access to policy élites: an analysis of tobacco industry documents. PLOS Med 2011:8:e1001076.

165 World Health Organization. Tobacco industry and corporate responsibility... an inherent contradiction. 2004 http://www.who.int/tobacco/communications/CSR_ report.pdf (accessed 23 Nov 2017).

166 Sanz C. Gravísima denuncia contra Philip Morris Por Fraude. http://periodicotribuna. com.ar/18065-gravisima-denuncia-contra-philip-morris-por-fraude-.html (accessed 25 Sep 2017).

167 Ross H. Tracking and tracing tobacco products in Kenya. Prev Med 2017:105S:S15-18.

168 European Commission. Implementing act under article 15(11) of the tobacco products directive 2014/40/EU. 2017 https://ec.europa.eu/info/law/betterregulation/initiatives/ares-2017-4305467_en - initiative-details (accessed 29 Sep 2017).

169 FCTC W. Industry interference in tracking and tracing of tobacco products. https:// seatca.org/dmdocuments/Note Verbal_Industry interference_4-Mar-2016.pdf (accessed 22 Jan 2018).

170 Justice.gov. R.J. Reynolds affiliate pleads guilty, pays $\$ 15$ million in criminal fines and forfeitures as part of cigarette smuggling operation. https://www.justice.gov/ archive/opa/pr/1998/December/605usa.htm (accessed 22 Nov 2017).

171 Woods A, Campion-Smith B. Big tobacco pays the price. https://www.thestar.com/ news/canada/2008/08/01/big_tobacco_pays_the_price.html (accessed 22 Nov 2017).

172 Non-Smokers' Rights Association. Physicians for a smoke-free Canada. Chronology of cigarette smuggling. $2001 \mathrm{http}: / /$ www.smoke-free.ca/pdf_1/rcmp-chron-2001.pdf (accessed 22 Nov 2017).

173 District Court US. European Community complaint against Philip Morris, RJ Reynolds and Japan Tobacco. New York: United States District Court, Eastern District of New York.

174 Joossens L, Raw M. Progress in combating cigarette smuggling: controlling the supply chain. Tob Control 2008;17:399-404.

175 JUSTIA US Law. U.S. Court of appeals for the second circuit - 355 F.3d 123 (2d Cir. 2004). Argued. https://law.justia.com/cases/federal/appellate-courts/F3/355/123/ 500439/ (accessed 22 Nov 2017)
176 World Health Organization. Parties to the WHO framework convention on tobacco control. 2017 http://www.who.int/fctc/signatories_parties/en/ (accessed 22 Nov 2017).

177 European Commission. Cooperation Agreement between British American Tobacco (Holdings) Limited and The European Union as represented by the European Commission and The Signatory Member States of the European Union. https:// ec.europa.eu/anti-fraud/sites/antifraud/files/docs/body/bat_main_agreement.pdf (accessed 25 Sep 2017).

178 European Commission. Co-operation Agreement dated as of 27 September 2010 among Imperial Tobacco Limited and The European Union Represented by the European Commission and Each Member State Listed on the Signature Pages Hereto. https://ec.europa.eu/anti-fraud/investigations/eu-revenue/imperial_tobacco_ en (accessed 25 Sep 2017).

179 European Commission. JT International S.A. JT International holding BV and the European Community and the participating member States - cooperation agreement. https://ec.europa.eu/anti-fraud/sites/antifraud/files/docs/body/cooperation_ agreement.pdf (accessed 25 Sep 2017).

180 European Commission. Anti-contraband and anti-counterfeit agreement and general release dated as of July 9, 2004 among Philip Morris International Inc., Philip Morris Products Inc., Philip Morris Duty Free Inc., and Philip Morris World Trade SARL, The European Community Represented by the European Commission and Each Member State Lised on the Signature Pages Hereto. https://ec.europa.eu/anti-fraud/sites/ antifraud/files/docs/body/agreement_2004.pdf (accessed 25 Sep 2017).

181 World Health Organization. Global tobacco treaty enters into force with 57 countries already committed. http://www.who.int/mediacentre/news/releases/2005/pro9/en/ (accessed 22 Nov 2017).

182 World Health Organization. Documentation in all official languages of the Conference of the Parties. undated. http://apps.who.int/gb/fctc/E/index.html (accessed 22 Nov 2017).

183 European Patent Office. European Patent Application 05792643.8 from PCT/ IB2005/003103 Of Philip Morris Products S.A. Methods and Systems for making, tracking and authentication of products. https://register.epo.org/application? documentld=EKONG7TR3785J13\&number=EP05792643\&lng=en\&npl=false (accessed 23 Nov 2017).

184 World Intellectual Property Organization. (W02006038114) Methods and systems for making, tracking and authentication of products. https://patentscope.wipo.int/ search/en/detail.jsf?docld=W02006038114\&recNum=1\&tab=NationalPhase\& maxRec $=\&$ office $=\&$ prevFilter $=\&$ sortOption $=\& q u e r y S t r i n g=($ accessed 23 Nov 2017).

185 European Patent Office. Decision to grant a European patent pursuant to Article 97(1) EPC. https://register.epo.org/application?documentld=EOM52XIF1875FI4\& number $=E P 05792643 \& \mid \mathrm{lng}=$ en\&npl=false (accessed 23 Nov 2017).

186 World Health Organization. Informal working group on a protocol to eliminate illicit trade in tobacco products. 2017 http://www.who.int/fctc/protocol/illicit_trade/iwg protocol/en/ (accessed 23 Nov 2017).

187 Moneyhouse. Digital coding and tracking association. 2017 https://www. moneyhouse.ch/fr/company/digital-coding-and-tracking-association-20635553611/ detail (accessed 23 Nov 2017).

188 Framework Convention Alliance. FCA Briefing Paper: INTERPOL's application for observer status. http://www.fctc.org/images/stories/FCA_policy_brief_INTERPOLS_ application.pdf (accessed 22 Nov 2017).

189 Kenya Revenue Authority. Re. Printing, Supply and Delivery of Security Revenue Stamps Complete with Track and Trace System and Integrated Production Accounting System, Letter to SICPA. 14 Dec 2012.

190 World Health Organization. Illicit trade protocol: ratification. 2017 http://www.who. int/fctc/protocol/ratification/en/ (accessed 23 Nov 2017).

191 European Patent Office. Request for transfer of rights - applicant. https://register.epo org/application?documentld=EUI86TDI1729228\&number=EP05792643\&lng=en\& npl=false (accessed 23 Nov 2017).

192 European Commission. Commissioner Semeta welcomes EU agreement to sign WHO Protocol against the illicit trade in tobacco. http://europa.eu/rapid/press-release_ MEMO-13-1115_en.htm (accessed 23 Nov 2017).

193 Patent US, Office T. United States patent application publication. https://docs.google. com/viewer?url=patentimages.storage.googleapis.com/pdfs/US20140122353.pdf (accessed 23 Nov 2017).

194 European Commission. Revision of the tobacco products directive 2014/40/EU. 2014 https://ec.europa.eu/health/tobacco/products/revision en (accessed 25 Sep 2017).

195 KPMG. Project sun: a study of the illicit cigarette market. 2017 https://home.kpmg. com/uk/en/home/insights/2015/05/project-sun-a-study-of-the-illicit-cigarettemarket.html (accessed 23 Nov 2017).

196 World Health Organization. Expert panel on illicit trade protocol. $2017 \mathrm{http}: / / \mathrm{www}$. who.int/fctc/protocol/activities/Expert_Panel_on_llicit_Trade_Protocol/en/ (accessed 23 Nov 2017).

197 Philip Morris International. Philip Morris International Launches New Initiative to Fight Smuggling and Related Crimes; Pledges USD 100 Million to Fund Projects. 2016 http://www.webcitation.org/6hzNRDcXt.

198 European Commission. Statement from VP Georgieva on green light from European Parliament for international treaty to fight tobacco smuggling. https://ec.europa. eu/commission/commissioners/2014-2019/georgieva/announcements/statement- 
vp-georgieva-green-light-european-parliament-international-treaty-fight-tobaccosmuggling_en (accessed 23 Nov 2017).

199 Tobacco Control Research Group. Codentify. TobaccoTactics.org. http://www. tobaccotactics.org/index.php?title=Codentify (accessed 23 Nov 2017).

200 European Commission. Inception impact assessment. http://ec.europa.eu/smartregulation/roadmaps/docs/2015_sante_694_695_696_ia_da_tpd_en.pdf (accessed 23 Nov 2017).

201 European Commission. Expiry of the agreement with Philip Morris International. https:// ec.europa.eu/commission/commissioners/2014-2019/georgieva/announcements/expiryagreement-philip-morris-international en (accessed 23 Nov 2017).

202 European Commission. Public consultation on the implementation of an EU system for traceability and security features pursuant to articles 15 and 16 of the tobacco products directive 2014/40/EU. https://ec.europa.eu/health/tobacco/consultations/ 2016_traceability_security_features_en (accessed 23 Nov 2017).

203 European Patent Office. P161125EP00, Application No./Patent No. 05792643.8 - 1959 / 1719070. https://register.epo.org/application?documentld= EZIBY4AX2428DSU\&number=EP05792643\&lng=en\&npl=false (accessed 23 Nov 2017).

204 Tobacco Manufacturers Association. Tobacco products directive (2014/40/EU). http:// the-tma.org.uk/policy-legislation/tobacco-products-directive/track-trace-securityfeatures/ (accessed 10 Oct 2017).

205 Ross H, Eads M, Yates M. Why governments cannot afford codentify to support their track and trace solutions. Tob Control 2018:tobaccocontrol-2017-053970.

206 Da Costa E, Silva VL. EU tobacco control policy must separate foxes from chickens. https://euobserver.com/opinion/132402 (accessed 25 Sep 2017).

207 Joossens L, Chaloupka F, Merriman D, et al. Issues in the smuggling of tobacco products. In: Jha P, Chaloupka F, eds. Tobacco Control in Developing Countries, 2000:293-406.

208 Gilmore $A B$, Fooks G, McKee M. A review of the impacts of tobacco industry privatisation: implications for policy. Glob Public Health 2011;6:621-42.

209 Evans-Reeves KA, Hatchard JL, Gilmore AB. 'It will harm business and increase illicit trade': an evaluation of the relevance, quality and transparency of evidence submitted by transnational tobacco companies to the UK consultation on standardised packaging 2012. Tob Control 2015;24:e168-77.
210 European Parliament. Parliamentary questions: answer given by Mr Šemeta on behalf of the Commission. http://www.europarl.europa.eu/sides/getAllAnswers.do? reference $=E-2010-011191$ \&language $=E N$ (accessed 16 Feb 2018).

211 World Customs Organization. Illicit trade report 2015. 2016 https://illicittrade.com/reports/ downloads/OMD_ITR_Complete_LR_2016_12_04.pdf (accessed 12 Jul 2017).

212 World Customs Organization. Illicit trade report 2014. 2015 https://illicittrade.com/ reports/downloads/WCO Illicit Trade Report 2014.pdf (accessed 26 Jul 2017).

213 World Customs Organization. Illicit trade report, 2012. 2013 http://www.wcoomd org/ /media/wco/public/global/pdf/topics/enforcement-and-compliance/activitiesand-programmes/illicit-trade-report/wco-report-2013-_-br.pdf?db=web (accessed 07 Nov 2017).

214 KPMG, Royal United Services Institute. Project sun: a study of the illicit cigarette market in the European Union, Norway and Switzerland. 2017 https://rusi.org/ publication/other-publications/project-sun-study-illicit-cigarette-market-europeanunion-norway-and (accessed 20 Dec 2017).

215 KPMG. Project sun: a study of the illicit market in the european union, Norway and Switzerland, 2015 Results. 2016 https://home.kpmg.com/uk/en/home/insights/2016/ 05/project-sun.html (accessed 07 Jan 2018).

216 KPMG. Project sun: a study of the illicit cigarette market in the European Union, Norway and Switzerland, 2014 Results. 2015 http://kpmg.co.uk/creategraphics/ 2015/06_2015/CRT026736/files/assets/basic-html/index.html.

217 KPMG. Project sun: a study of the illicit cigarette market in the European Union, 2013 results. 2014 https://www.pmi.com/resources/docs/default-source/pmisustainability/sun-report-2013.pdf?sfvrsn=0 (accessed 07 Jan 2017).

218 KPMG. Project star 2012 results, 2013.

219 KPMG. Project star - 2011 results, 2012.

220 KPMG. Project star 2010 results, 2011.

221 MacGregor J. Operation Henry: Tackling the supply of illicit tobacco products in England 2014. Commissioned by the department of health tobacco policy team. 2014 https://www.tradingstandards.uk/media/documents/policy/improving-thehealth-of-society/oh_final_for_publciation-1.pdf (accessed 10 Jul 2017).

222 Rasmussen JJ. Letter to commissioner general, Kenya Revenue Authority. 17 Apr 2012.

223 Hopkins P. Draft letter to KRA, email to FractureCode and BAT, 2012.

224 Manford E. RE: KRA tender email to Jacob Juul Rasmussen. 16 Apr 2012.

225 Manford E. KRA tender, email to Jacob Juul Rasmussen. 4 May 2012. 